\title{
Extracorporeal circulation
}

\author{
Domingo M. BRAILE*
}

Cardiac surgery with extracorporeal circulation was considered a major medical achievement in the twentieth century, as well as an improvement in the field of biological sciences [1-6]. It may be compared to the conquest of outer space and the arrival of humans to the moon.

We can also compare it with developments triggered by the atomic domain, which allowed the production of large amounts of energy from matter.

Unfortunately, the atomic energy achievement also allowed man to the creation of destructive weapons, putting at risk the integrity of the planet.

Unlike this invention, the advent of extracorporeal circulation has created new possibilities for curing heart disease never imagined in the first half of last century.

The possibility to correct heart defects under direct vision was an old dream insistently pursued by many professionals despite repeated failures that frustrated those who ventured to replace the pump function of the heart, and the respiratory and ventilatory functions of the lungs.

Nowadays, it is difficult for young people to imagine the countless difficulties faced by a surgeon to be able to divert all the blood from the patients to an external circuit to keep them alive.

Entering the heart chambers was made possible by this discovery in an almost bloodless field and to correct birth [7-10] or acquired defects [11-15], which restricted the lives of those who had the misfortune to present problems in the blood propulsive organ and in their own lives.

I could do a retrospect of all the experiments conducted by renowned scientists, before all the knowledge and material conditions leading this battle into a successful outcome.

The history of cardiac surgery is a real saga that treading the path toward this far-reaching scientific and social achievement, had to overcome prejudices and taboos [1-6].

Plenty of other knowledge came along with this new technology relating to the physiology of circulation, the body's reactions to surgical aggressions and the domain knowledge in relation to the internal environment, in which all our cells are immersed and where metabolism is developed with the production of energy that makes us live [16-27]. These studies resulted in the understanding of homeostasis, a complex system of self-regulation responsible to maintain the multiple vital parameters within normal levels, during production of the energy previously cited.

Catabolites, heat, carbon dioxide, acids, water and other chemicals elements are resulted from this process and must be processed and /or eliminated.

It allowed great advances both in Medicine and Research, not only restricted to the cardiovascular system, but benefiting in a conspicuous way from the knowledge required in all fields of Biology.

I mention, as examples, the understanding of variations in acid-base and hydrosaline balance, indispensable for achieving these systems stability during extracorporeal circulation.

These knowledge do not only have benefits for the cardiovascular surgery, but for all specialties, creating basic concepts to patient care during large and small surgical interventions, including the subsequent postoperative period. Since this field of physiology was dominated, it was possible to understand the consequences of acid-base and hydrosaline imbalances in critical states, such as cardiogenic shock, septic shock and many others. It is also essential for the multidisciplinary team that performs cardiac surgery - including cardiac surgeons, anesthesiologists, perfusionists, intensivists, nurses, physiotherapists, psychologists, in other words, the whole support group to understand that experience from years of practice and studies within this attractive field result in the security offered to patients nowadays.

In particular, the perfusionist has great responsibility during the surgical procedure, since they virtually have in their hands and under their eyes the life of the patient who is being operated.

In this period, when the blood circulation and breathing are being artificially maintained, the organic physiology must be monitored and adjusted to stay within the strictest parameters of normality.

The study of gas exchange is essential for the proper conduct of Extracorporeal Circulation. If they are not properly known, keeping the patient in perfect condition for the supply of oxygen and substrates is impossible, followed by the carbon dioxide and catabolites removal in 
the best way possible. Temperature control throughout the operation is another aspect of great importance and its implications, both in the period of hypothermia which is often necessary to decrease metabolism, as in the warm-up period, should be part of the whole team and the perfusionist's sound knowledge, when performing the surgical act.

Deep hypothermia with circulatory arrest is a procedure that goes beyond our imagination, giving us the possibility to fully stop the circulation for an hour or more, and after the warm up, conducted with strict criteria, see the patient back to their state of homeothermic metabolism and life.

This technique allows us to restore lesions in complex congenital heart disease in children with very low weight or, more generally, in areas of difficult access, giving the surgeon the opportunity to work with bloodless field in the correction of defects that would otherwise be impossible to correct.

The study of equipment and knowledge of every detail in its operation are essential [28-30], not only for the perfusionist, as for the whole team, that should work in perfect understanding, thus no detail escapes from the correct and instant observation of the person in charge, avoiding jeopardizing the patient's life, as well as their physical and mental integrity $[31,32]$.

The air intake in the arterial circuit is a disastrous oversight, which totally dependent on the continued attention of the perfusionist, who may possibly be aided in this occupation by sensors that detect bubbles, disrupting the blood pumping and sounding alarms.

In fact, the cardiac surgery with extracorporeal circulation is a highly complex procedure and it should be understood this way.

The professionals must have deep knowledge in order to perform it safely, strongly embedded in their thinking, thus their decisions are automatic and immediate.

In pursuance of these skills, two assumptions should be considered: solid theoretical knowledge and extensive training services that are able to teach with competence, responsibility and safety the professionals who are dedicated to specific functions in this area.

I had the privilege of experiencing almost the entire evolution of cardiac surgery in the last 50 years, and strongly believe that taking part in this "adventure" was an experience that can not be described in simple words.

It was a wonderful experience that left me with the indelible mark of a successful major achievement in the field of Medicine and Surgery.

However, the supreme challenge to the golden rule of Cardiac Surgery remains: On the day after the operation, the patient should be stable, awake, alert and extubated. Any eventual bleeding will already have stopped, diuresis will be within normal parameters, as well as the routine tests. The patient is ready to be transferred to the ICU room. One more patient was then saved and our mission was accomplished!

\section{* Professor Emeritus, PhD in Cardiac Surgery at FAMERP and UNICAMP, Editor of the Brazilian Journal of Cardiovascular Surgery.}

\section{REFERENCES}

1. Braile DM, Gomes WJ. Evolução da cirurgia cardiovascular: a saga brasileira. Uma história de trabalho, pioneirismo e sucesso. Arq Bras Cardiol. 2010;94(2):151-2.

2. Braile DM. História da Cirurgia Cardíaca. Arq Bras Cardiol. 1996;66(6):329-37.

3. Gomes WJ, Saba JC, Buffolo E. 50 anos de circulação extracorpórea no Brasil: Hugo J. Felipozzi, o pioneiro da circulação extracorpórea no Brasil. Rev Bras Cir Cardiovasc. 2005;20(4):1-6.

4. Prates PR. Pequena história da cirurgia cardíaca: e tudo aconteceu diante de nossos olhos... Rev Bras Cir Cardiovasc. 1999;14(3):177-84.

5. Costa IA. História da cirurgia cardíaca brasileira. Rev Bras Cir Cardiovasc. 1998;13(1):1-7.

6. Prates PR. Abomba. Rev Bras Cir Cardiovasc. 2010;25(3):V-VI.

7. Canale LS, Monteiro A, Colafranceschi AS, Pinto DF. Tática de canulação em miniesternotomia superior para o tratamento cirúrgico de cardiopatias congênitas. Rev Bras Cir Cardiovasc. 2010;25(2):245-8.

8. Lenzi AW, Miyague NI, Ferreira WS, Sallum FS. Mortalidade hospitalar na cirurgia de reconstrução da via de saída do ventrículo direito com homeonxerto pulmonar. Rev Bras Cir Cardiovasc. 2010;25(1):25-31.

9. Furlanetto G, Henriques SS, Pasquinelli FS, Furlanetto BHS. Nova técnica: translocação aórtica e pulmonar com preservação da valva pulmonar. Rev Bras Cir Cardiovasc. 2010;25(1):99-102.

10. Furlanetto G, Furlanetto BHS, Henriques SS, Kapins CEB, Lopes LM, Olmos MCC, et al. Nova técnica: Operação de Norwood com perfusão regional cerebral e coronariana. Rev Bras Cir Cardiovasc. 2009;24(4):447-52. 
11. Poffo R, Pope RB, Selbach RA, Mokross CA, Fukuti F, Silva Júnior I, et al. Cirurgia cardíaca videoassistida: resultados de um projeto pioneiro no Brasil. Rev Bras Cir Cardiovasc. 2009;24(3):318-26.

12. Haddad R, Fagundes WV, Pinheiro BB. Aortoplastia redutora com contenção externa associada à troca valvar aórtica em pacientes de alto risco. Rev Bras Cir Cardiovasc. 2009;24(2):194-9.

13. Alves Júnior L, Rodrigues AJ, Évora PRB, Basseto S, Scorzoni Filho A, Luciano PM, et al. Fatores de risco em septuagenários ou mais idosos submetidos à revascularização do miocárdio e ou operações valvares. Rev Bras Cir Cardiovasc. 2008;23(4):550-5.

14. Benfatti RA, Pontes JCDV, Gomes OM, Dias AEMÁS, Gomes Júnior JF, Gardenal N, et al. Substituição valvar mitral com papilopexia cruzada e constrição anular em pacientes com insuficiência cardíaca. Rev Bras Cir Cardiovasc. 2008;23(3):372-7.

15. Silva VF, Real DSS, Branco JNR, Catani R, Kim HC, Buffolo E, et al. Operação de Bentall e De Bono para correção das doenças da raiz aórtica: análise de resultados a longo prazo. Rev Bras Cir Cardiovasc. 2008;23(2):256-61.

16. Mota AL, Rodrigues AJ, Évora PRB. Circulação extracorpórea em adultos no século XXI. Ciência, arte ou empirismo? Rev Bras Cir Cardiovasc. 2008;23(1):78-92.

17. Felicio ML, Andrade RR, Castiglia YMM, Silva MAM, Vianna PTG, Martins AS, et al. Cistatina C e taxa de filtração glomerular em cirurgia cardíaca com circulação extracorpórea. Rev Bras Cir Cardiovasc. 2009;24(3):305-11.

18. Antunes N, Dragosavc D, Petrucci Junior O, Oliveira PPM, Kosour C, Blotta MHSL, et al. Ultrafiltração para remover mediadores inflamatórios durante circulação extracorpórea na revascularização do miocárdio. Rev Bras Cir Cardiovasc. 2008;23(2):175-82.

19. Torina AG, Petrucci O, Oliveira PPM, Severino ESBO, Vilarinho KAS, Lavagnoli CFR, et al. Efeitos da ultrafiltração modificada na função pulmonar e necessidade de hemotransfusão em pacientes submetidos à revascularização do miocárdio. Rev Bras Cir Cardiovasc. 2010;25(1):59-65.

20. Ferreira CA, Vicente WVA, Évora PRB, Rodrigues AJ, Klamt JG, Carlotti APCP, et al. Aprotinina não influencia troponina I, NTproBNP e função renal em crianças operadas com circulação extracorpórea. Rev Bras Cir Cardiovasc. 2009;24(4):519-32.

21. Ferreira CA, Vicente WVA, Évora PRB, Rodrigues AJ, Klamt JG, Carlotti APCP, et al. Aprotinina preserva plaquetas em crianças com cardiopatia congênita acianogênica operadas com circulação extracorpórea? Rev Bras Cir Cardiovasc. 2009;24(3):373-81.

22. Figueiredo LC, Araújo S, Abdala RCS, Abdala A, Guedes CAV. CPAP de $10 \mathrm{cmH} 2 \mathrm{O}$ durante a circulação extracorpórea não melhora a troca gasosa pós-operatória. Rev Bras Cir Cardiovasc. 2008;23(2):209-15.

23. Rocha TS, Silveira AS, Botta AM, Ricachinevsky CP, Mulle LD, Nogueira A, et al. Lactato sérico como marcador de morbimortalidade no pós-operatório de operação de Jatene em lactentes. Rev Bras Cir Cardiovasc. 2010;25(3):350-8.

24. Passaroni AC, Silva MAM, Martins AS, Kochi AC. Uso de nifedipina e incidência de lesão renal aguda em pós-operatório de cirurgia de revascularização do miocárdio com CEC. Rev Bras Cir Cardiovasc. 2010;25(1):32-7.

25. Evora PRB, Ribeiro PJF, Vicente WVA, Reis CL, Rodrigues AJ, Menardi AC, et al. Azul de metileno no tratamento da síndrome vasoplégica em cirurgia cardíaca. Quinze anos de perguntas, respostas, dúvidas e certezas. Rev Bras Cir Cardiovasc. 2009;24(3):279-88

26. Dussin LH, Moura L, Gib MC, Saadi EK, Barbosa GV, Wender $\mathrm{OCB}$, et al. Análise ultra-estrutural do miocárdio usando solução cardioplégica cristalóide com e sem procaína em pacientes submetidos à troca valvar aórtica. Rev Bras Cir Cardiovasc. 2008;23(3):389-95.

27. Silveira Filho LM, Petrucci Jr O, Carmo MR, Oliveira PPM, Vilarinho KAS, Vieira RW, et al. Trimetazidina como aditivo em solução cardioplégica sem pré-tratamento não traz proteção adicional ao miocárdio isquêmico: estudo em modelo suíno de coração isolado. Rev Bras Cir Cardiovasc. 2008;23(2):224-34.

28. Finoti RG, Braile DM, Croti UA, Oliveira MAB, Godoy MF, Leal JCF, et al. Avaliação de oxigenador de membrana infantil em ovinos. Rev Bras Cir Cardiovasc. 2008;23(3):358-64.

29. Vieira Junior FU, Vieira RW, Antunes N, Petrucci O, Oliveira PP, Serra MMP, et al. Análise do perfil hidrodinâmico em diferentes modelos de bombas de rolete utilizadas em circulação extracorpórea. Rev Bras Cir Cardiovasc. 2009;24(2):188-93.

30. Vieira Junior FU, Vieira RW, Costa ET, Antunes N, Junior OP, Oliveira PPM, et al. Visualização de refluxo em aspirador de sangue e reservatório de cardiotomia usados em circulação extracorpórea. Rev Bras Cir Cardiovasc. 2009;24(4):533-9.

31. Martin JFV, Melo ROV, Sousa LP. Disfunção cognitiva após cirurgia cardíaca. Rev Bras Cir Cardiovasc. 2008;23(2):245-55.

32. Souza HJB, Moitinho RF. Estratégias para redução do uso de hemoderivados em cirurgia cardiovascular. Rev Bras Cir Cardiovasc. 2008;23(1):53-9. 